\title{
УДК 536.7
}

\section{ENERGY TRANSFORMATIONS IN MECHANICAL SYSTEMS}

\author{
A. Sokolenko, O. Stepanets, O. Boyko \\ National University of Food Technologies
}

\begin{tabular}{|c|c|}
\hline Key words: & \begin{tabular}{|c|} 
ABSTRACT \\
\end{tabular} \\
\hline $\begin{array}{l}\text { mechanical systems, } \\
\text { energy transformations, } \\
\text { energy recovery, } \\
\text { friction, } \\
\text { dissipation }\end{array}$ & $\begin{array}{l}\text { The article presents theoretical generalizations concerning } \\
\text { energy transformations in mechanical systems. Studies are } \\
\text { related to transient processes of overclocking and escape of } \\
\text { systems under the influence of external factors in the form of } \\
\text { forces and reactions of bonds. The relative displacements in the }\end{array}$ \\
\hline $\begin{array}{l}\quad \text { Article history: } \\
\text { Received 07.09.2019 } \\
\text { Received in revised form } \\
06.10 .2019 \\
\text { Accepted } 19.11 .2019\end{array}$ & $\begin{array}{l}\text { kinematic pairs of machines and mechanisms in the products by } \\
\text { the values of the friction coefficients determine the level of } \\
\text { dissipation, so the possibilities of recovery are limited to the } \\
\text { values of the kinetic energy of the moving masses of the } \\
\text { systems. The materials on the threefold task concerning dyna- }\end{array}$ \\
\hline $\begin{array}{l}\text { Corresponding author: } \\
\text { mif63@i.ua }\end{array}$ & $\begin{array}{l}\text { mic loads, speed and energy costs of technological processes } \\
\text { are presented. From this point of view, the set of } 8 \text { laws of } \\
\text { motion is considered and none of them corresponds to the } \\
\text { extreme conditions of the lowest dynamic loads and energy } \\
\text { costs. } \\
\text { The possibility of kinetic energy recovery in escape modes } \\
\text { with the minimization of the driving forces at the levels of } \\
\text { friction overcoming is shown. } \\
\text { From the point of view of the interests of energy recovery, } \\
\text { systems of cyclic action in which opportunities to use the } \\
\text { kinetic energy of the escape modes in parallel synchronized } \\
\text { asymmetric acceleration processes deserve special attention. } \\
\text { Another area of energy recovery concerns the limitation of the } \\
\text { quantities of friction planes and force interactions in mobile } \\
\text { joints under conditions of rigid kinematic bonds. } \\
\text { The transfer of kinetic energy in friction transmissions in } \\
\text { transient conditions is possible in the directions from more fast- } \\
\text { moving to less-fast-moving elements and in the free-run modes } \\
\text { after equalization of speeds in the contact zone, it is possible to } \\
\text { change the roles of the master and slave masses. The presence } \\
\text { of such energy redistributions leads to the conclusion that it is } \\
\text { possible to solve the problems of kinetic energy recovery in } \\
\text { machine systems. }\end{array}$ \\
\hline
\end{tabular}

DOI: $10.24263 / 2225-2916-2019-26-20$

(C) А. І. Соколенко, О. І. Степанець, О. О. Бойко, 2019 


\title{
ЕНЕРГЕТИЧНІ ТРАНСФОРМАЦІЇ В МЕХАНІЧНИХ CИCTEMAX
}

\author{
А. І. Соколенко, д-р техн. наук \\ О. І. Степанець, канд. техн. наук \\ О. О. Бойко, канд. техн. наук \\ Національний університет харчових технологій
}

У статті наведено теоретичні узагальнення, які стосуються енергетичних трансорормацій у механічних системах. Дослідження пов'язані з перехідними процесами розгону та вибігу систем під дією зовнішніх фракторів у формі сил $i$ реакцій зв'язків. Відносні переміщення в кінематичних парах машин і механізмів в добутках на значення коефіцієнтів тертя визначають рівень дисипації, тому можливості рекуперації максимально обмежуються значеннями кінетичної енергії рухомих мас систем. Представлено матеріали про триєдину задачу, яка стосується динамічних навантажень, швидкодії і енергетичних затрат на виконання технологічних процесів. 3 иієї точки зору розглянуто сукупність восьми законів руху і показано, що жоден з них не відповідає екстремальним умовам найменших динамічних навантажень та енергетичних витрат. Показано можливість рекуперації кінетичної енергії в режимах вибігу з мінімізацією роботи рушійних сил на рівнях роботи на подолання тертя.

Ключові слова: механічні системи, енергетичні трансформації, рекуперація енергії, тертя, дисипація.

Постановка проблеми. Виконання будь-якого процесу потребує відповідного рушійного фактора. Так, у механічній системі, пов'язаній з переміщенням вантажів, забезпечується дія сил рушійних і сил опору, різниця між якими зрівноважується силою інерції. При цьому за інших рівних умов важливим фактором впливу виступає маса вантажу 3 приєднаними масами рухомих складових приводів. Саме співвідношення між приведеними масами і різницею рушійних факторів і факторів опору визначає кінематику й динаміку перебігу таких процесів [1-3]. 3 точки зору можливостей впливу на результат виконання процесу варіації стосуються вказаних сил і мас [4]. Математичне відображення в загальній постановці в таких пошуках відповідає другому і третьому законам Ньютона і одночасно принципу Д’Аламбера [7] і ця відповідність 3 певним наближенням може бути записана у формі:

$$
m \ddot{x}=P_{p y u}(t, x, \dot{x})-P_{o n}(t, x, \dot{x}),
$$

де приведена маса $\mathrm{m}$ і силові фактори $P_{p y ш}$ i $P_{\text {on }}$, представлені функціями часу, координати переміщення х, швидкості $\dot{x}$ зміни координати тощо.

Присутність прискорення $\ddot{x}$ в умові (1) вказує на можливість оцінки процесу переміщення з розгорткою у часі за ії інтегрування.

У найпростішому варіанті маси і силові параметри виступають як сталі величини, але й за таких умов існує доцільність пошуку їх співвідношень, які мають привести до певного кінцевого результату. Останній може стосуватися таких факторів, як обмежене динамічне навантаження (сила інерції $m \ddot{x}$ ), час перебігу процесу й енергетичні витрати на його здійснення [5; 6]. Очевидно, що вибір критерію оптимізації стосується одного з параметрів при певних обмеженнях інших або кількох 3 них. 
Мета дослідження визначена у формі узагальнення, яке стосується доповнення задачі динаміки машин оцінками можливостей енергетичної рекуперації в періоди перебігу перехідних процесів у технологічному обладнанні харчових виробництв.

Матеріали і методи. Дослідження теоретичне, виконано на основі законів фізики, принципів і методів механіки зі створенням та аналізом аналітичних моделей.

Результати дослідження. Звертання до задачі мінімізації енергетичних витрат на реалізацію процесу означає необхідність оцінки їх складових, пов'язаних, наприклад, з переміщеннями вантажу на величину кінцевої координати $x_{(\kappa)}$. При цьому енергетичні витрати, які стосуються необхідності подолання сил опору $P_{o n}, \epsilon$ незворотними, а робота рушійної сили проти сил інерції визначається рівнем кінетичної енергії рухомих мас у кожний плинний момент часу $t$ :

$$
E_{\text {кін }}=m \frac{(\dot{x})^{2}}{2} .
$$

На момент завершення етапу розгону маємо максимальне значення кінетичної енергії за кінцевої швидкості $\dot{x}_{(\kappa)}$ :

$$
E_{\kappa i н(\max )}=m \frac{\left(\dot{x}_{(\kappa)}\right)^{2}}{2},
$$

а цьому перехідному процесу відповідає енергетичне співвідношення:

$$
m \frac{(\dot{x})^{2}}{2}=P_{p y u} x-P_{o n} x,
$$

звідки робота рушійної сили:

$$
A_{\text {pym }}=P_{\text {pym }} x=0,5 m(\dot{x})^{2}+P_{\text {on }} x .
$$

Припинення дії рушійної сили означає завершення етапу розгону і початок етапу вибігу, в якому кінетична енергія $E_{\text {кін(max) }}$ виступає в ролі енергетичного підгрунтя рушійного фактора у формі:

$$
\begin{gathered}
m \ddot{x}^{I I}=-P_{o n} ; \\
\dot{x}^{I I}=\dot{x}_{(\kappa)}^{I}-\frac{P_{o n}}{m} t^{I I} ; \quad t_{(\kappa)}^{I I}=\frac{\dot{x}_{(\kappa)}^{I} m}{P_{o n}},
\end{gathered}
$$

де $\dot{x}_{(\kappa)}^{I}$ - кінцева швидкість першого етапу; $\dot{x}^{I I}-$ плинна швидкість на другому етапі; $t_{(\kappa)}^{I I}$ — час перебігу другого етапу.

Оскільки першому етапу відповідають залежності:

то звідси маємо:

$$
\dot{x}^{I}=\frac{P_{p y u}-P_{o n}}{m} t \quad i \quad \dot{x}^{I}=-\frac{P_{p y u}-P_{o n}}{m} \cdot \frac{t^{2}}{2},
$$

$$
t_{(\kappa)}^{I}=\sqrt{\frac{2 x_{(\kappa)}^{I} m}{P_{p y u}-P_{o n}}} ; \quad x_{(\kappa)}^{I}=\frac{P_{p y u}-P_{o n}}{m} \cdot \frac{t_{(\kappa)}^{2}}{2} .
$$

Відповідно до принципу суперпозиції загальні за два етапи значення складуть: 


$$
x_{\text {заг }}=x_{(\kappa)}^{I}+x_{(\kappa)}^{I I} ; \quad t_{\text {заг }}=t_{(\kappa)}^{I}+t_{(\kappa)}^{I I},
$$

а кількість рекуперованої енергії має значення, що відповідає умові (3).

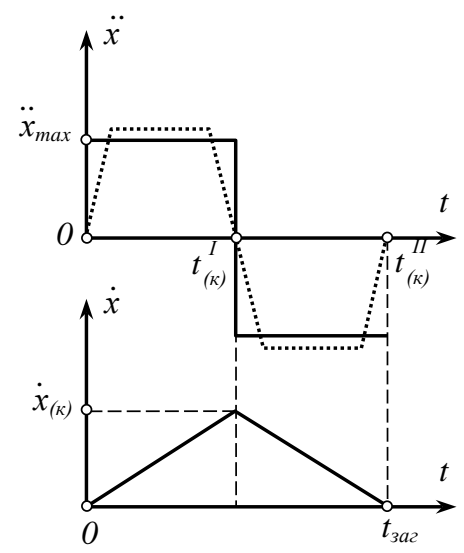

Рис. 1. Кінематичні діаграми переміщень

Оцінка перебігу переміщень приведеної маси на двох етапах приводить до висновку, що в загальному випадку незалежно від прийнятих законів руху досягаються можливості оцінки динамічних складових навантажень і енергетичних витрат. Останні пов'язані, зокрема, з необхідністю подолання сил інерції на етапі розгону на рівні досягнутої кінетичної енергії рухомих мас системи, яка змінюється від нуля до максимуму на етапі розгону і від максимуму до нуля - на етапі вибігу. Різним законам руху приведених мас відповідають режими з різними значеннями максимумів швидкостей, а тому у зв’язку з перспективами рекуперації саме кінетичної енергії слід оцінювати режими вибігу, визначаючи відповідну координату переходу до нього. Очевидно, що режим вільного вибігу означає повне використання кінетичної енергії, за якого величина переміщення залежить від сили опору, що відповідає залежності:

$$
x_{(\kappa)}^{I I}=\dot{x}_{(\kappa)}^{I} t_{(\kappa)}^{I I}-f g \frac{\left(t_{(\kappa)}^{I I}\right)^{2}}{2} .
$$

При $t_{(\kappa)}^{I I}=\dot{x}^{I} / f g$ отримаємо:

$$
x_{(\kappa)}^{I I}=\frac{\left(x_{(\kappa)}^{I}\right)^{2}}{f g}-f g\left(\frac{x_{(\kappa)}^{I}}{f g}\right)^{2} .
$$

3 наведеного видно, що за сталих значень параметрів $\mathrm{m}, P_{p y m}$ i $P_{o n}$ на першому етапі досягається рівноприскорений рух, а на другому - рівносповільнений. Якщо модулі прискорень на обох етапах збігаються, то це відповідає режиму швидкодії за мінімізованих динамічних навантажень порівняно з іншими можливими законами руху. Однак такий подвоєний позитивний результат супро- 
воджується недоліком, пов'язаним з присутністю м’яких динамічних ударів (рис. 1) у формі стрибкоподібних прискорень на початку імпульсного переміщення, на переході від першого етапу до другого і після завершення режиму вибігу. Очевидно, що збільшення різниці $P_{p y и}-P_{\text {on }}$ супроводжується зростанням динамічних навантажень. Реалізація таких законів можлива за рахунок відповідної кінематики механізмів приводів (наприклад, за використання кулачкових механізмів) або за рахунок використання відповідних заходів мехатронного забезпечення заданого параметра:

$$
P_{\text {pym }}=m \ddot{x}-P_{o n} .
$$

В останньому випадку реалізуються можливості ліквідації явищ м'яких динамічних ударів за рахунок лінійних законів $\ddot{x}=\ddot{x}(t)$ у перехідних процесах.

Виконаний аналіз щодо закономірностей (рис. 1) в інтересах імпульсних переміщень робочих органів приводить до висновку щодо доцільності досягнення умов рекуперації кінетичної енергії. Очевидно, що повній рекуперації відповідають співвідношення:

$$
t_{(\kappa)}^{I I}<t_{(\kappa)}^{I} ; \quad t_{(\kappa)}^{I I}=t_{(\kappa)}^{I} \quad i \quad t_{(\kappa)}^{I I}>t_{(\kappa)}^{I},
$$

однак лише за випадку $t_{(\kappa)}^{I I}=t_{(\kappa)}^{I}$ досягається режим швидкодії. За розрахункових співвідношень $t_{(\kappa)}^{I I}>t_{(\kappa)}^{I}$ кінематична реалізація закону швидкодії рекуперацію режиму вибігу обмежує або відміняє за рахунок додаткової сили опору $P_{o n}^{\prime}$ з боку робочого органа. При цьому рівняння руху має вигляд:

$$
\ddot{x}^{I I}=-\frac{P_{o n}^{\prime}}{m}-f g,
$$

з якого одержуємо:

$$
\dot{x}^{I I}=\dot{x}_{(\kappa)}^{I}-\frac{P_{o n}^{\prime}}{m} t-f g t
$$

і звідси при $\dot{x}_{(\kappa)}^{I I}=0$ отримаємо:

$$
\frac{P_{o n}^{\prime}}{m} t_{(\kappa)}^{I I}=\dot{x}_{(\kappa)}^{I}-f g t_{(\kappa)} \quad i \quad P_{o n}^{\prime}=\frac{\dot{x}_{(\kappa)}^{I} m}{t_{(\kappa)}^{I I}}-f m g .
$$

Величина переміщення на другому етапі відображується залежністю:

$$
\dot{x}^{I I}=\dot{x}_{(\kappa)}^{I} t-\left(\frac{P_{o n}^{\prime}}{m}+f g\right) \frac{t^{2}}{2},
$$

а повному переміщенню відповідає умова:

$$
x_{(\kappa)}^{I I}=\dot{x}_{(\kappa)}^{I} t_{(\kappa)}^{I I}-\left(\frac{P_{o n}^{\prime}}{m}+f g\right) \frac{\left(t_{(\kappa)}^{I I}\right)^{2}}{2} .
$$

Енергетичні витрати, пов’язані з подоланням сил тертя на другому етапі, становлять: 


$$
E_{m e p}=f m g\left(\dot{x}_{(\kappa)}^{I} t_{(\kappa)}^{I I}-\left(\frac{P_{o n}^{\prime}}{m_{n p}}+f g\right)\left(\frac{\left(t_{(\kappa)}^{I I}\right)^{2}}{2}\right) .\right.
$$

Тоді з урахуванням енергетичного балансу в системі робота сил кінематичного забезпечення:

$$
E_{\kappa i н}=m \frac{\left(\dot{x}_{(\kappa)}\right)^{2}}{2}-f m g\left(\dot{x}_{(\kappa)}^{I} t_{(\kappa)}^{I I}-\left(\frac{P_{o n}^{\prime}}{m}+f g\right) \frac{\left(t_{(\kappa)}^{I I}\right)^{2}}{2}\right) .
$$

Перехід до режиму вільного вибігу означає, що рушійний фактор припиняє дію на момент часу $t_{(\kappa)}^{I}$. За випадку кінематичного забезпечення другого етапу енергетичним співвідношенням відповідають умови (17) і (18). Це означає, що роль рушійних факторів виконують сили інерції, а забезпечення заданої кінематики супроводжується протидією додаткової сили опору, яка генерується в приводі у формі різних реакцій. Присутність останніх у діях на певних переміщеннях визначає ту частину енергетичних витрат, що відповідають $E_{\text {кін }}$. Сама кінематика, наприклад, мальтійського механізму, забезпечує обов'язкову і позиціоновану зупинку веденої маси 3 трансформацією кінетичної енергії в роботу проти сил тертя з відповідною енергетичною втратою.

У виконаному аналізі здійснено звертання до рівноприскорених і рівносповільнених переміщень рухомих мас системи у зв'язку з сукупністю відгуків у формі динаміки навантажень, часу перебігу і можливостей енергетичної рекуперації. Однак у більшості випадків завдання теорії механізмів і машин та динаміки машин зосереджені на визначенні динамічних навантажень [7] і тільки перехід до розділу регулювання ходу машин стосується енергетичних співвідношень за взаємодій мас ведучих, проміжних і ведених. В останньому випадку здійснюється перехід від одномасових систем до дво- і кількамасових. Наявність перехідних процесів у системах рухомих мас означає перерозподіл динамічних параметрів i енергетичних трансформацій. При цьому динамічні параметри є наслідками змін прискорень, які, у свою чергу, визначаються змінами швидкостей. У зв’язку з цим динаміка навантажень доповнюється аналізом енергетичних трансформацій 3 пошуком можливостей рекуперації кінетичної енергії.

На основі продовження подальших міркувань підкреслимо, що саме кінетична енергія приведеної маси системи $m V_{\max }^{2} / 2$ визначає складову енергетичних витрат на розгін системи. Це означає можливість порівняльної оцінки системи з різними законами руху на основі амплітуд швидкостей і прискорень або їх аналогів. Умовою виконання теоретичних досліджень $є$ прийняття однакових параметрів циклічних переміщень х у проміжках однакових значень часу $t$, або узагальненої координати $\varphi$ [6; 8]. При цьому вважаємо, що в порівнюваних випадках значення х збігаються зі значеннями фазових кутів $\varphi$ за відповідних узагальнених швидкостей $\omega$. За реперний закон прийнято параболічний, поглиблений аналіз якого склав вступну частину цього дослідження, а результати порівняння наведені в таблиці з відображенням 
співвідношень аналогів швидкостей $\mathrm{i}$ прискорень для різних законів $d^{2} x / d \varphi^{2}=f^{\prime \prime}(\varphi)$.

Таблиия. Амплітуди аналогів швидкостей і прискорень для різних законів $d^{2} x / d \varphi^{2}=f^{\prime \prime}(\varphi)$

\begin{tabular}{|c|c|c|c|c|c|}
\hline \multirow{2}{*}{$\begin{array}{l}\text { Закон } \\
\text { руху }\end{array}$} & \multirow{2}{*}{ Графік $\frac{d^{2} x}{d \varphi^{2}}=f^{\prime \prime}(x)$} & \multicolumn{2}{|c|}{ Максимальне значення } & \multirow{2}{*}{$\begin{array}{l}\text { Співвідно- } \\
\text { шення } \\
\text { аналогів } \\
\text { швидко- } \\
\text { стей }\end{array}$} & \multirow{2}{*}{$\begin{array}{c}\text { Співвідно- } \\
\text { шення } \\
\text { аналогів } \\
\text { приско- } \\
\text { рень }\end{array}$} \\
\hline & & $\frac{d x}{d \varphi}, \mathrm{M}$ & $\frac{d^{2} x}{d \varphi^{2}}, \mathrm{M}$ & & \\
\hline 1 & 2 & 3 & 4 & 5 & 6 \\
\hline 1. Лінійний & $\stackrel{\varphi+\infty}{\underset{-\infty}{\longrightarrow}}$ & $\frac{x_{(\kappa)}}{\varphi_{1}}$ & $\pm \infty$ & 0,5 & $\infty$ \\
\hline $\begin{array}{c}\text { 2a. Парабо- } \\
\text { лічний }\end{array}$ & $\left\lceil\mathrm{y}_{\max }^{\prime \prime} \varphi\right.$ & $2 \frac{x_{(\kappa)}}{\varphi_{1}}$ & $4 \frac{x_{(\kappa)}}{\varphi_{1}^{2}}$ & 1,0 & 1,0 \\
\hline $\begin{array}{l}\text { 2б. Несиме- } \\
\text { тричний }\end{array}$ & 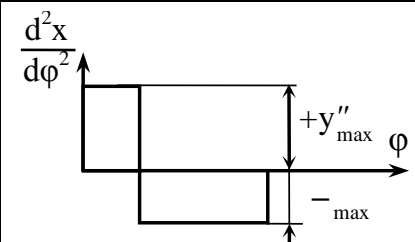 & $2 \frac{x_{(\kappa)}}{\varphi_{1}}$ & $\begin{array}{l}+2(1+k) \frac{x_{(\kappa)}}{\varphi_{1}^{2}} \\
-\frac{2(1+k)}{k} \cdot \frac{x_{(\kappa)}}{\varphi_{1}^{2}}\end{array}$ & 1,0 & $\begin{array}{l}+0,5(1+\mathrm{k}) \\
-0,5(1+\mathrm{k})\end{array}$ \\
\hline $\begin{array}{l}\text { 3. Модифіко- } \\
\text { ваний } \\
\text { лінійний }\end{array}$ & 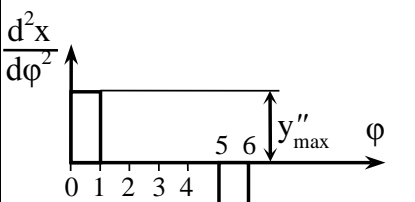 & $1,2 \frac{x_{(\kappa)}}{\varphi_{1}}$ & $7,2 \frac{x_{(\kappa)}}{\varphi_{1}^{2}}$ & 0,6 & 1,8 \\
\hline 4. Трикугний & $\stackrel{\frac{\mathrm{d}^{2} \mathrm{x}}{\mathrm{d} \varphi^{2}} \uparrow}{ }$ & $2 \frac{x_{(\kappa)}}{\varphi_{1}}$ & $8 \frac{x_{(\kappa)}}{\varphi_{1}^{2}}$ & 1,0 & 2,0 \\
\hline $\begin{array}{l}\text { 5. Косинусої- } \\
\text { дальний }\end{array}$ & $\frac{d^{2} x}{d \varphi^{2}} \uparrow$ & $\frac{\pi}{2} \cdot \frac{x_{(\kappa)}}{\varphi_{1}}$ & $\frac{\pi^{2}}{2} \cdot \frac{x_{(\kappa)}}{\varphi_{1}^{2}}$ & 1,57 & 1,23 \\
\hline
\end{tabular}




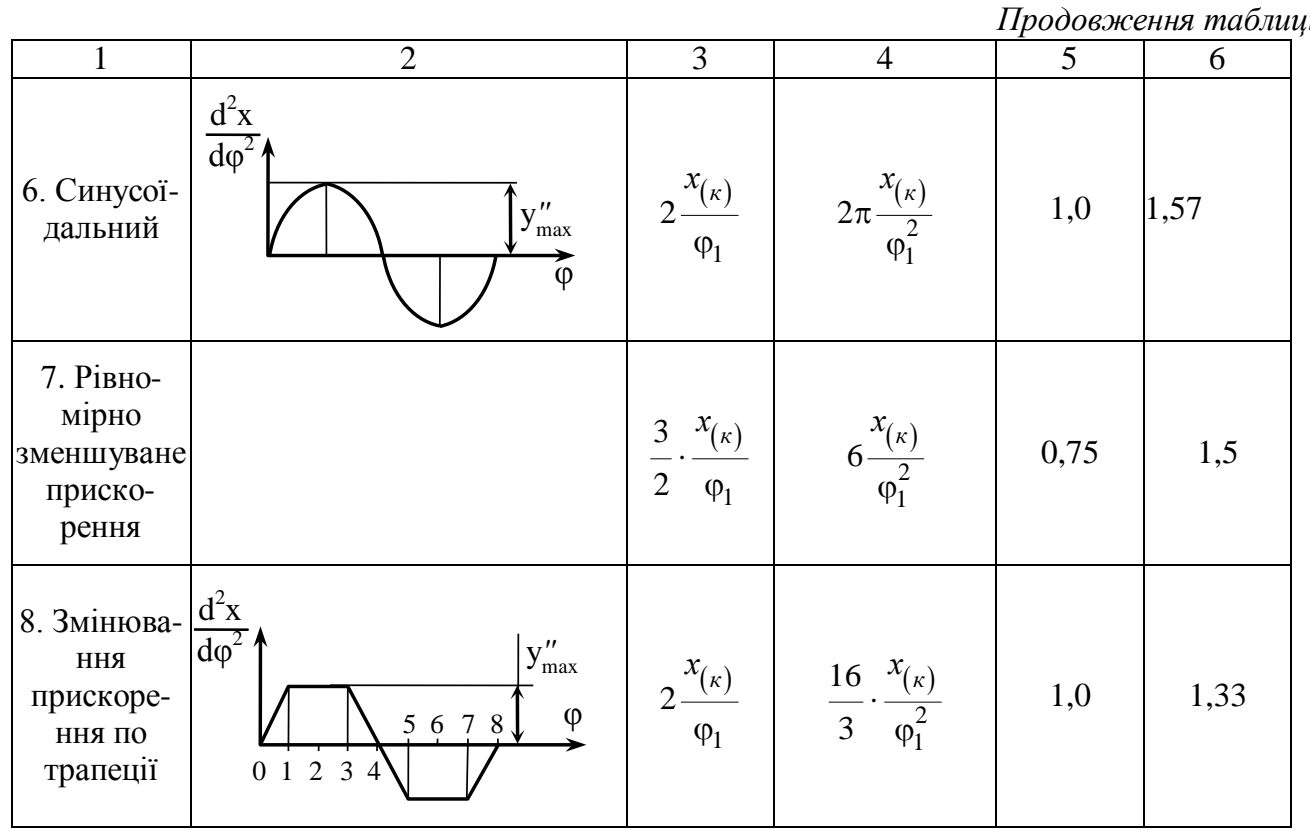

Одержані результати у формі відношень амплітуд аналогів швидкостей і прискорень різних законів до відповідних параметрів параболічного закону в ряди за ранжиром:

- для аналогів швидкостей

\begin{tabular}{|c|c|c|c|c|c|c|c|c|}
\hline 0,5 & 0,6 & 0,75 & 1,0 & 1,0 & 1,0 & 1,0 & 1,0 & 1,57 \\
\hline (1) & (3) & $(7)$ & $(2 \mathrm{a})$ & $(26)$ & (4) & (6) & (8) & (5) \\
\hline \multicolumn{9}{|c|}{ - для аналогів прискорень } \\
\hline 1,0 & $0,5(1+\mathrm{k})$ & 1,23 & 1,33 & 1,5 & 1,57 & 1,6 & 2,0 & $\infty$ \\
\hline$(2 a)$ & $(26)$ & (5) & (8) & (7) & (6) & (3) & (4) & (1) \\
\hline
\end{tabular}

Наведені рядки порівняльних даних супроводжуються адресними відмітками, що відповідають номерам законів, наведеним у таблиці. Очевидно, що жоден із них не відповідає екстремальним умовам найменших динамічних навантажень і енергетичних витрат. Це означає, що остаточний вибір на користь того чи іншого закону має здійснюватися на основі прийнятних умов за обома показниками.

Особливістю першого ряду є наявність однакових максимальних швидкостей у п’яти законах. Серед них трапецеїдальний закон є однією з найкращих комбінацій швидкостей і прискорень.

Одержані математичні формалізації стосуються достатньо спрощених вхідних умов, а тому для підтвердження узагальнень на їх основі звернемося до випадку переміщень ведених мас похилими площинами (рис. 2).

Нехай маса m розміщена на похилій площині, що утворює 3 лінією горизонту кут $\alpha$ і здійснює циклічне переміщення під дією рушійної сили $P_{p у м}$. У цьому випадку опір переміщенню стосується складової сил тяжіння $m g \sin \alpha$, а рівняння руху на першому етапі записується у формі:

$$
m \ddot{x}=P_{p y u}-F_{m}-m g \sin \alpha
$$

або за підстановки $F_{m}=f m g \cos \alpha$ маємо: 


$$
\ddot{x}=\frac{P_{p y u}}{m}-f g \cos \alpha-g \sin \alpha .
$$

Звідси на першому етапі робота рушійних сил складає:

$$
A_{p y m}=\frac{m V_{(\kappa)}^{2}}{2}+f m g \cos \alpha x_{(\kappa)}^{I}+m g \sin \alpha x_{(\kappa)}^{I} .
$$

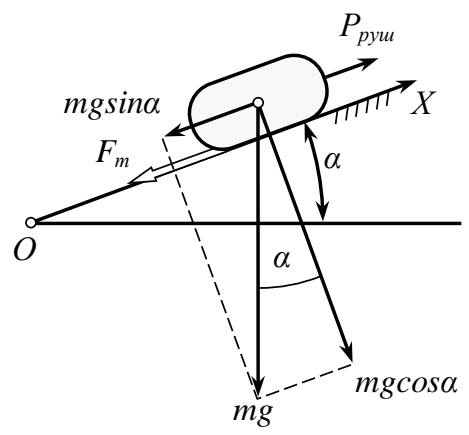

\section{Рис. 2. Розрахункова схема для випадку переміщення вантажу похилою площиною}

Оскільки добуток $x_{(\kappa)}^{I} \cos \alpha$ дорівнює горизонтальній проекції координати $x_{(\kappa)}^{I}$, то це означає, що робота рушійної сили на похилій площині проти сил тертя дорівнює енергетичним витратам на переміщення на відстані вказаної проекції. Одночасно складова $m g \sin \alpha x_{(\kappa)}^{I}$ відповідає потенціальній енергії переміщення маси $\mathrm{m}$ у гравітаційному полі. Очевидно, що ця енергетична складова може бути повенена в систему, наприклад, за рахунок гравітаційного опускного пристрою. Останнє у своєрідній формі відображує закон збереження енергії з вказівною та те, що незворотні енергетичні втрати пов'язані тільки із силами зовнішнього і внутрішнього тертя у випадках пружних систем.

На другому етапі переміщення зі сталою швидкістю при $\ddot{x}^{I I}=0$ енергетичні витрати складуть:

$$
A_{p y m}^{I I}=f m g x_{(\kappa)}^{I I} \cos \alpha+m g x_{(\kappa)}^{I I} \sin \alpha .
$$

Третьому етапу відповідають умови:

$$
\begin{gathered}
\ddot{x}^{I I I}=-f g \cos \alpha-g \sin \alpha ; \quad \dot{x}^{I I I}=-(f g \cos \alpha+g \sin \alpha) t+V_{(\kappa)} ; \\
t_{(\kappa)}^{I I I}=\frac{V_{(\kappa)}}{f g \cos \alpha+g \sin \alpha} .
\end{gathered}
$$

При цьому рекуперована частина енергії становить значення $m V_{(\kappa)}^{2} / 2$, а робота сил рушійних на загальному переміщенні визначається залежністю:

$$
A_{\text {заг }}=(f m g \cos \alpha+m g \sin \alpha)\left(x_{(\kappa)}^{I}+x_{(\kappa)}^{I I}+x_{(\kappa)}^{I I I}\right) .
$$

Наведені приклади аналізу систем транспортування вантажів показують можливість рекуперації кінетичної енергії в режимах вибігу з мінімізацією енергетичних витрат на рівні роботи рушійних сил на подолання сил тертя. При цьому має місце енергетична трансформація роботи рушійних сил в кінетичну енергію рухо- 
мих мас на етапах розгону і в теплову енергію, пов'язану з проявами сил тертя, а швидкодія виконання циклічних процесів залежить від різниці рушійних сил і сил опору, що визначає динамічні навантаження. Такий перелік особливостей формулює перелік вимог щодо синтезу систем:

- швидкодія перебігу процесу;

- обмежені динамічні навантаження;

- рекуперація кінетичної енергії.

Очевидно, що ця сукупність має внутрішню триєдність через співвідношення швидкостей, прискорень і мас. Значення швидкостей визначають швидкодію, зміна швидкостей — прискорення, а наслідком останніх є динамічні навантаження. Роль певного регулятора належить приведеній масі системи, що в теорії і практиці регулювання ходу машин зводиться до використання маховикових мас. Значною мірою це пов'язано з існуванням в технологічних машинах мас з різними кінематичними параметрами і різними рівнями кінетичних енергій, які впливають на режими вибігу і рекуперацію останніх.

На підтвердження цього положення звернемося до випадку двомасової системи 3 фрикційним зв'язком (рис. 3) з обертальними рухами ведучої маси 3 моментом інерції $I_{2}$. Фрикційна муфта дає змогу здійснювати режими вибігу вказаних мас як в роз'єднаному, так і в об'єднаних станах. Нехай за роз'єднаної муфти маси знаходяться в режимі вибігу, долаючи відповідно моменти сил опору $M_{\text {on.1 }}$ i $M_{\text {on.2 }}$ 3 початковими швидкостями $\omega_{(n) 1}$ і $\omega_{(n) 2}$ за початкових значень кінетичної енергії $E_{(n) 1}$ і $E_{(n) 2}$. Таким вибігам відповідають рівняння:

$$
I_{1} \frac{d \omega_{1}}{d t}=-M_{\text {on. } 1} ; \quad I_{2} \frac{d \omega_{2}}{d t}=-M_{o n .2} .
$$

За вказаних параметрів і початкових умов маємо:

$$
\omega_{1}=\omega_{(n) 1}-\frac{M_{o n .1}}{I_{1}} t ; \quad \omega_{2}=\omega_{(n) 2}-\frac{M_{o n .2}}{I_{2}} t .
$$

Завершується режими вибігу значеннями $\omega_{1}=0$ i $\omega_{2}=0$, що відповідає часу завершення $t_{(\kappa) 1}$ i $t_{(\kappa) 2}$, i фізиці явища у формі: час вибігу мас прямо пропорційний початковим кутовим швидкостям і обернено пропорційний моментам сил опору:

$$
t_{(\kappa) 1}=\omega_{(n) 1} \frac{I_{1}}{M_{\text {on. } 1}} ; \quad t_{(\kappa) 2}=\omega_{(n) 2} \frac{I_{2}}{M_{\text {on.2 }}} .
$$

Змінам кінетичної енергії відповідають умови:

$$
E_{1}=\frac{I_{1}}{2}\left(\omega_{(n) 1}-\frac{M_{o n .1}}{I_{1}} t\right)^{2} ; \quad E_{2}=\frac{I_{2}}{2}\left(\omega_{(n) 2}-\frac{M_{o n .2}}{I_{2}} t\right)^{2} .
$$

Об’єднання мас 1 та 2 фрикційною муфтою приводить до іншого режиму, в якому одна 3 них відіграє роль ведучої, а друга — веденої. Роль ведучої буде належати тій, яка має більшу кутову швидкість, а не більший рівень кінетичної енергії. Припустимо, що має місце співвідношення $\omega_{(n) 1}>\omega_{(n) 2}$ на момент замиканням муфти з моментом тертя в ній $M_{m}$. Першому етапу при цьому відповідають рівняння руху:

$$
I_{1} \frac{d \omega_{1}}{d t}=-M_{m}-M_{o n .1} ; \quad I_{2} \frac{d \omega_{2}}{d t}=M_{m}-M_{o n .2} .
$$


Хоча рівняння (28) об’єднані в систему, однак спільним для них є тільки $M_{m}$ і їх розв’язання здійснюється окремо:

$$
\omega_{1}=\omega_{(n) 1}-\frac{M_{m}+M_{o n .1}}{I_{1}} t ; \quad \omega_{2}=\omega_{(n) 2}+\frac{M_{m}-M_{o n .2}}{I_{2}} t .
$$

Завершується етап за вирівнювання швидкостей, коли $\omega_{(\kappa) 1}^{I}=\omega_{(\kappa) 2}^{I}$, а час вибігу складає:

$$
t_{(\kappa)}^{I}=\frac{\omega_{(n) 1}-\omega_{(n) 2}}{\frac{M_{m}-M_{o n .2}}{I_{2}}+\frac{M_{m}+M_{o n .1}}{I_{1}}} .
$$

Підстановка $t_{(\kappa)}^{I}$ в одну з умов (29) дає змогу записати:

$$
\omega_{(\kappa)}=\omega_{(n) 1}-\frac{M_{m}+M_{o n .1}}{I_{1}} \cdot \frac{\omega_{(n) 1}-\omega_{(n) 2}}{\frac{M_{m}-M_{o n .2}}{I_{2}}+\frac{M_{m}+M_{o n .1}}{I_{1}}} .
$$

За час перебігу першого етапу сумісного вибігу без урахування втрат на тертя від першої маси до другої передається енергії:

$$
\begin{gathered}
\Delta E_{\kappa}=\frac{I_{1}}{2}\left(\omega_{(n) 1}^{2}-\omega_{(\kappa)}^{2}\right)= \\
=\frac{I_{2}}{2}\left[\omega_{(n) 1}^{2}-\left(\omega_{(n) 1}-\frac{M_{m}+M_{o n .1}}{I_{1}} \cdot \frac{\omega_{(n) 1}-\omega_{(n) 2}}{\left.\left.\frac{M_{m}-M_{o n .2}}{I_{2}}+\frac{M_{m}+M_{o n .1}}{I_{1}}\right)\right] .} .\right.\right.
\end{gathered}
$$

На наступному другому етапі режими вибігу мас будуть різношвидкісними $\mathrm{i}$ залежатимуть від моментів опору і моментів інерції $I_{1}$ та $I_{2}$.

Висновки. Енергетичні трансформації в технологічних машинах відображаються співвідношеннями рушійних факторів і опорів та масових характеристик i стосуються перехідних процесі розгону і вибігу механічних систем. 3 точки зору інтересів енергетичної рекуперації на підвищену увагу заслуговують системи циклічної дії, в яких досягаються можливості використовувати кінетичну енергію режимів вибігу в паралельних синхронізованих асиметричних процесах розгону. Інший напрямок енергетичної рекуперації стосується обмеження кількостей площин тертя і силових взаємодій в рухомих з'єднаннях в умовах жорстких кінематичних зв'язків.

Передавання кінетичної енергії у фрикційних передачах в умовах перехідних процесів можливе у напрямках від більш швидкохідних до менш швидкохідних елементів і в режимах вільних вибігів після вирівнювання швидкостей у зоні контактування можливою є зміна ролей ведучої і веденої мас. Наявність таких енергетичних перерозподілів приводить до висновку про можливість вирішення задач рекуперації кінетичної енергії в машинних системах.

\section{ЛІТЕРАТУРА}

1. Якимчук М. В. Науково-технічні засади створення обладнання для групового пакування харчових продуктів на основі мехатронних модулів: автореф. дис. ... д-ра техн. наук: 05.18.12 / Якимчук Микола Володимирович; Нац. ун-т харч. технол. — Київ, 2016. $-38 \mathrm{c}$. 
2. Функціонально-модульне проектування пакувальних машин: монографія / О. М. Гавва, Л. О. Кривопляс-Володіна, С. В. Токарчук та ін. - Київ: Видавництво «Сталь», 2015. - 547 с.

3. Стоцько 3. А. Моделювання технологічних систем: навч. посіб.; друге видання, перероб. і доп. / 3. А. Стецько. - Львів: «Львівська політехніка», 2013. - 188 с.

4. Пальчевський Б. О. Дослідження технологічних систем. Моделювання, проектування, оптимізація: навч. посіб. для студ. техн. спец. вищ. навч. закл. / Б. О. Пальчевський. - Львів: «Світ», 2001. - 232 с.

5. Патент 58946 UA, МПК В65B 5/10 (2006.01). Пристрій для переміщення вантажів / Соколенко А. І., Шевченко О. Ю., Піддубний В. А., Максименко І. Ф., Шевченко А. О.; заявник та патентовласник Національний університет харчових технологій. № u201012737; заявл. 27.10.2010; опубл. 26.04.2011, Бюл. № 8, 2011 p.

6. Соколенко А. І. Про можливість рекуперації кінетичної енергії в машинах і механізмах / А. І. Соколенко, К. В. Васильківський, В. С. Костюк // Харчова промисловість. - 2016. - № 19. - С. 92-99.

7. Теория механизмов и механика машин: учеб. для вузов / К. В. Фролов, С. А. Попов, А. К. Мусатов, Г. А. Тимофеев; под. Ред. Г. А. Тимофеева. Изд. 6-е испр. и доп. - Москва: Издательство МГТУ им. Н.Э. Баумана, 2009. - 688 с.

8. Криворотько В. М. Динаміка і рекуперація вторинних енергетичних ресурсів у механічних системах / В. М. Криворотько, А. І. Соколенко, К. В. Васильківський // Наукові праці НУХТ. — 2014. — Т. 20, № 1. - С. 171-180.

\title{
ЭНЕРГЕТИЧЕСКИЕ ТРАНСФОРМАЦИИ В МЕХАНИЧЕСКИХ СИСТЕМАХ
}

\author{
А. И. Соколенко, О. И. Степанец, А. О. Бойко \\ Национальный университет пищевых технологий
}

В статье приведены теоретические обобщения, касающиеся энергетических трансформаций в механических системах. Исследования связаны с переходными процессами разгона и выбега систем под действием внешних фракторов в форме сил и реакций связей. Относительные перемещения в кинематических парах машин и механизмов в произведениях на значения коэфрфициентов трения определяют уровень диссипации, поэтому возможности рекуперации максимально ограничиваются значениями кинетической энергии движущихся масс систем. Представлены материалы о триединой задаче, которая касается динамических нагрузок, быстродействия и энергетических затрат на выполнение технологических процессов. С этой точки зрения рассмотрена совокупность восьми законов движения и показано, что ни один из них не coответствует экстремальным условиям наименьших динамических нагрузок и энергетических затрат. Показана возможность рекуперации кинетической энергии в режимах выбега с минимизацией работы движущих сил на уровнях работы на преодоление трения. Ключевые слова: механические системы, энергетические трансформации, рекуперация энергии, трения, диссипация. 